\title{
Influence of phosphorus stress on ammonium uptake by maize
}

J. V. de Magalhães , V. M. C. Alves , R. F. de Novais , P. R. Mosquim , J. R Magalhães, A. F. C. Bahia Filho \& D.M. Huber

To cite this article: J. V. de Magalhães , V. M. C. Alves , R. F. de Novais , P. R. Mosquim , J. R Magalhães , A. F. C. Bahia Filho \& D.M. Huber (2000) Influence of phosphorus stress on ammonium uptake by maize, Journal of Plant Nutrition, 23:2, 263-273, DOI: 10.1080/01904160009382013

To link to this article: https://doi.org/10.1080/01904160009382013

册 Published online: 21 Nov 2008.

Submit your article to this journal $\pi$

Џ Article views: 32

Q View related articles $₫$

4 Citing articles: 2 View citing articles 


\title{
Influence of Phosphorus Stress on Ammonium Uptake by Maize ${ }^{1}$
}

\author{
J. V. de Magalhães, ${ }^{a}$ V. M. C. Alves, ${ }^{a}$ R. F. de Novais, ${ }^{b}$

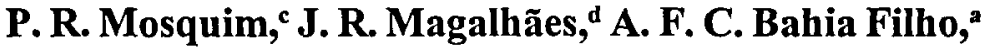 \\ and D.M. Huber ${ }^{e, 2}$
}

${ }^{2}$ National Maize and Sorghum Research Center/EMBRAPA, CP 151, 35701-970 Minas Gerais, Brazil

${ }^{b}$ Department of Soils and Plant Nutrition/Federal University of Viçosa, 36571-000 Viçosa, Minas Gerais, Brazil

${ }^{\mathrm{c}}$ Department of Plant Biology, Federal University of Viçosa, 36570-000 Viçosa, Minas Gerais, Brazil

${ }^{\mathrm{d}}$ CENARGEN/EMBRAPA, SAIN-70,770-900 Brasilia, DF, Brazil

'Department of Botany and Plant Pathology, Purdue University, West

Lafayette, IN 47907

\section{ABSTRACT}

The effect of phosphorus $(\mathrm{P})$ starvation on ammonium $\left(\mathrm{NH}_{4}\right)$ uptake was evaluated by growing single-cross seedlings of the male progenitor of the maize double-cross hybrid BR 201 in nutrient solution. The kinetics of $\mathrm{NH}_{4}$ uptake were measured after $P$ starvation and non-starvation periods of 2, 4, 6, 8 , and 10 days. The effect of $P$ addition during the study period (resupply) was also tested. Ammonium uptake decreased $45.7 \%$ after two days of $P$

\footnotetext{
'This research was supported by the Maize and Sorghum Research Center, EMBRAPA, and by a scholarship from CNPq-Brazil.

${ }^{2}$ Corresponding author (e-mail address: huber@btny.purdue.edu).
} 
stress compared to the fully P-sufficient control. Ammonium uptake decreased $83.0 \%$ when $\mathrm{P}$ was withheld for 10 days. The decline in $\mathrm{NH}_{4}$ uptake was partially reversed when $P$ was resupplied during the early periods of $P$ deficiency, but this effect diminished as the $P$ stress increased. These results suggest that maize plants are physiologically dependent on $\mathrm{NH}_{4}$ rather than nitrate $\left(\mathrm{NO}_{3}\right)$ when under $\mathrm{P}$ stress.

\section{INTRODUCTION}

The general chemical characteristics of acid tropical soils are conducive for periods of $\mathrm{P}$ stress for crops. Since visual symptoms of nitrogen $(\mathrm{N})$ deficiency are not always corrected by the application of $\mathrm{N}$, but may be corrected by the application of phosphate fertilizers, the possibility of a limiting P supply disturbing $\mathrm{N}$ uptake was indicated. Reduced $\mathrm{NH}_{4}$ uptake as a consequence of $\mathrm{P}$ deficiency has been described in buckwheat, barley, rape (Schhørring, 1986), and algae (Vona et al., 1992).

The first detailed characterization of $\mathrm{NH}_{4}$ uptake was provided in rice by Wang et al. (1993). Ammonium influx is biphasic and mediated by two discrete transport systems. In the low $\mathrm{NH}_{4}$ external concentration range (below $1 \mathrm{mmol} \mathrm{L}^{-1}$ ), influx occurs via a saturable high affinity transport system (HATS), whereas from 1 to 40 $\mathrm{mmol} \mathrm{L}^{-1}$ of external $\mathrm{NH}_{4}$, a second, non-saturable low affinity transport system (LATS) becomes operational. A saturable and high affinity transport system across the plasmatic membrane has been described in maize (Glass and Siddiqi, 1995). Results of inhibitor studies on the transmembrane electrical potential difference (Wang et al., 1994) as well as on ${ }^{13} \mathrm{NH}_{4}$ influx (Wang et al., 1993), provide evidence for $\mathrm{NH}_{4}$ transport to be dependent on the proton motive force.

The two transport systems (HATS and LATS) have different mechanisms for energy coupling with the HATS system being more electrogenic than LATS (Wang et al., 1994). Considering the occurrence of $P$ stress in acid tropical soils and the physiological evidence for $\mathrm{NH}_{4}$ uptake being dependent on metabolic energy, it was proposed that an inadequate $P$ supply may be one of the most important factors disturbing $\mathrm{N}$ uptake in these areas. As a consequence of an inadequate supply of $\mathrm{P}, \mathrm{N}$ utilization could be severely limited in tropical areas. The aim of this work was to identify the main changes in $\mathrm{NH}_{4}$ uptake by maize plants caused by increasing periods of $P$ starvation.

\section{MATERIALS AND METHODS}

Seeds of the male progenitor of the maize double-cross hybrid BR 201 were germinated in paper rolls in pots containing deionized water. After emergence, 30 uniform seedlings were transplanted to each of eight plastic receptacles containing $13 \mathrm{~L}$ of Steinberg's Nutrient Solution, pH 5.5, as modified by Foy et al. (1967). 
Aeration was kept constant and the solution was changed every two days. Seven days after the plants had grown in a complete nutrient solution in the greenhouse, $P$ was omitted from half of the solutions while a normal $P$ supply was maintained in the other half. Plants were transferred to a growth chamber with $25.3 \pm 0.5^{\circ} \mathrm{C}$ average day temperature, $19.3 \pm 0.9^{\circ} \mathrm{C}$ average night temperature, $71.7 \pm 2.3 \%$ relative humidity, and $540 \mu \mathrm{E} \mathrm{m}^{-2} \mathrm{~s}^{-1}$ light intensity. The effects of $P$ withdrawal for $2,4,6,8$, and 10 days on the kinetics of $\mathrm{NH}_{4}$ uptake were measured. Phosphorus resupply during the study period was also evaluated. The treatments were arranged as a $2 \times 2$ factorial, random block design with four replications. Plants were divided into four treatments: i) plants deficient in $\mathrm{P}$ prior to and during the study period (-P-P), ii) plants deficient in $\mathrm{P}$ prior to the study, but supplied $\mathrm{P}$ during the study period $(-P+P)$, iii) plants initially supplied $P$ but $P$ witheld during the study period $(+P-P)$, and iv) plants provided $\mathrm{P}$ both before and during the study period $(+\mathrm{P}+\mathrm{P})$. Two days before initiation of the kinetic studies, two uniform plants were transplanted to each individual pot containing the respective nutrient solution. The kinetic solution was composed of $100 \mu \mathrm{mol}$ ammonium nitrate $\left(\mathrm{NH}_{4} \mathrm{NO}_{3}\right) \mathrm{L}^{-1}$ and $50 \mu \mathrm{mol}$ calcium chloride $\left(\mathrm{CaCl}_{2}\right) \mathrm{L}^{-1}$ for all treatments. Treatments receiving $\mathrm{P}$ during the kinetic period ( $+\mathrm{P}+\mathrm{P}$ and $-\mathrm{P}+\mathrm{P})$, received $100 \mu \mathrm{mol}$ potassium dihydrogen phosphate $\left(\mathrm{KH}_{2} \mathrm{PO}_{4}\right) \mathrm{L}^{-1}$. After one hour (time to reach the steady state), the treatment solution was renewed and $10 \mathrm{~mL}$ of this solution were withdrawn every 30 minutes for nine hours and immediately frozen for later $\mathrm{NH}_{4}$ analysis. The plants were harvested at the end of the experiment, split into roots and shoots, dried at $70^{\circ} \mathrm{C}$, weighed, and ground.

Ammonium in the treatment solution was determined by flow injection analysis as described by Alves et al. (1993). Data from the depletion curves were corrected for $\mathrm{NH}_{4}$ lost due to sampling. The solution volume was corrected for evapotranspiration and sampling loss, and the results are presented as $\mathrm{NH}_{4}$ uptake curves (Figure 1).

\section{RESULTS}

\section{Dry Matter Accumulation}

Dry matter accumulation in shoots was significantly reduced after 6,8 , and 10 days of $P$ starvation (Table 1). Although not significant, shoot dry matter tended to be lower after four days of $P$ stress. Root dry matter accumulation was not significantly decreased by any period of $P$ starvation.

\section{Ammonium Uptake}

Ammonium uptake was based on the slope of the linear portion of the curves (Figure 1) as estimated by linear regression coefficients. The average rates of $\mathrm{NH}_{4}$ uptake for the four treatments are shown in Table 2. To evaluate an observed slope change due to $\mathrm{P}$ resupply $(-\mathrm{P}+\mathrm{P}$ treatment), the break-point time was the time where 


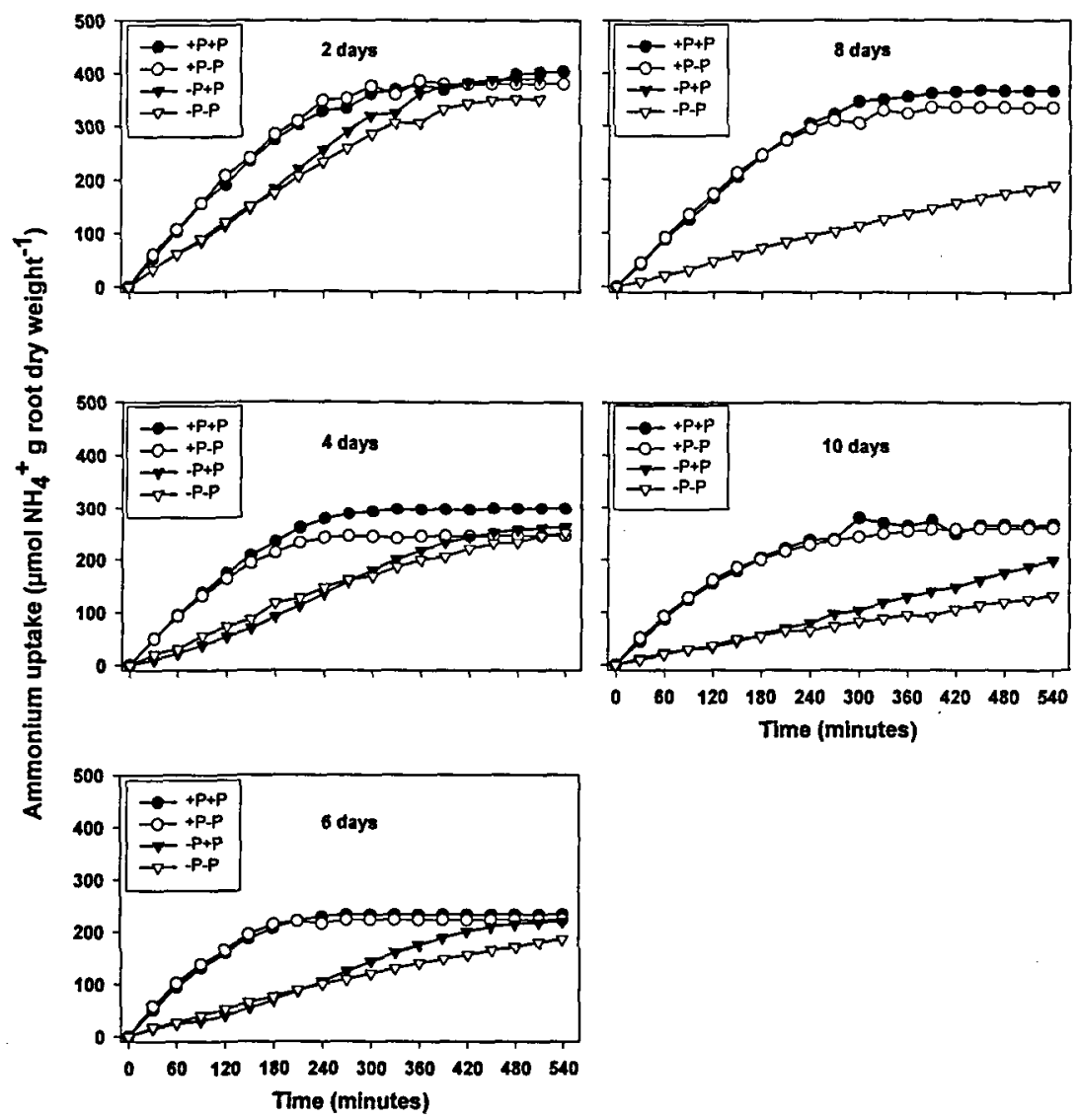

FIGURE 1. Ammonium uptake by maize after $2,4,6,8$, and 10 days. Treatments: $-\mathrm{P}-\mathrm{P}=$ plants without phosphorus before and during the study period, $-\mathrm{P}+\mathrm{P}=$ plants without phosphorus before but supplied phosphorus during the study period, $+\mathrm{P}-\mathrm{P}=$ plants receiving phosphorus prior to but not during the study period, and $+\mathrm{P}+\mathrm{P}=$ plants supplied phosphorus prior to and during the study period. Values are the averages of four replications (the $-\mathrm{P}+\mathrm{P}$ : 8 days sample was lost).

the $-\mathrm{P}+\mathrm{P}$ curve exceeded the -P-P curve at each period (Figure 1). The break-point for non- $\mathrm{P}$ stress curves $(+\mathrm{P}+\mathrm{P}$ and $+\mathrm{P}-\mathrm{P})$ and $-\mathrm{P}-\mathrm{P}$ curves, was the one corresponding to the best $\mathrm{r}^{2}$ calculated by linear regression. Slope statistical significance and statistical homogeneity between slopes were tested by Student's-t test (Steel and Torrie, 1960). Pair-wise comparisons between rates are shown in Table 2. 
TABLE 1. Dry matter accumulation in maize shoots and roots.

\begin{tabular}{|c|c|c|c|c|c|}
\hline \multirow[b]{2}{*}{ Treatment ${ }^{a}$} & \multicolumn{5}{|c|}{ Sampling period (days) } \\
\hline & 2 & 4 & 6 & 8 & 10 \\
\hline & & -3 & issue ( $\mathrm{g} \mathrm{p}$ & & \\
\hline$+\mathrm{P}+\mathrm{P}$ & $1.37 \mathrm{~A}^{\mathrm{b}}$ & $2.01 \mathrm{~B}$ & $3.05 \mathrm{~A}$ & $4.14 \mathrm{~A}$ & $5.87 \mathrm{~A}$ \\
\hline$+P-P$ & $1.34 \mathrm{~A}$ & $2.35 \mathrm{~A}$ & $3.26 \mathrm{~A}$ & $4.27 \mathrm{~A}$ & $5.92 \mathrm{~A}$ \\
\hline$-P+P$ & $1.37 \mathrm{~A}$ & $1.91 \mathrm{~B}$ & $2.37 \mathrm{~B}$ & $2.40 \mathrm{~B}$ & $2.70 \mathrm{~B}$ \\
\hline -P-P & $1.40 \mathrm{~A}$ & $1.86 \mathrm{~B}$ & $2.28 \mathrm{~B}$ & $2.47 \mathrm{~B}$ & $2.69 \mathrm{~B}$ \\
\hline \multirow[t]{2}{*}{${ }^{*}$ C.V. $(\%)$} & 14.48 & 4.71 & 8.68 & 12.84 & 16.07 \\
\hline & \multicolumn{5}{|c|}{--Root tissue (g per pot) } \\
\hline$+P+P$ & $0.41 \mathrm{~A}$ & $0.55 \mathrm{~A}$ & $0.72 \mathrm{~A}$ & $0.80 \mathrm{~A}$ & $1.12 \mathrm{~A}$ \\
\hline$+\mathrm{P}-\mathrm{P}$ & $0.43 \mathrm{~A}$ & $0.68 \mathrm{~A}$ & $0.75 \mathrm{~A}$ & $0.85 \mathrm{~A}$ & $1.14 \mathrm{~A}$ \\
\hline$-\mathrm{P}+\mathrm{P}$ & $0.44 \mathrm{~A}$ & $0.63 \mathrm{~A}$ & $0.77 \mathrm{~A}$ & $0.83 \mathrm{~A}$ & $1.07 \mathrm{~A}$ \\
\hline$-P-P$ & $0.46 \mathrm{~A}$ & $0.64 \mathrm{~A}$ & $0.78 \mathrm{~A}$ & $0.91 \mathrm{~A}$ & $1.24 \mathrm{~A}$ \\
\hline${ }^{*}$ C.V.V. $(\%)$ & 16.72 & 10.0 & 10.56 & 9.16 & 17.39 \\
\hline
\end{tabular}

${ }^{2}$ Treatments: $-P-P=$ plants without phosphorus before and during the study period, $-\mathrm{P}+\mathrm{P}$-plants without phosphorus before, but supplied phosphorus during the study period, $+\mathrm{P}-\mathrm{P}=$-plants receiving phosphorus prior to, but not during the study period, and $+\mathrm{P}+\mathrm{P}=$ plants supplied phosphorus prior to and during the study period.

'Dry matter averages (four replications) followed by the same letter in the columns are not statistically different at the $1 \%$ level of probability (Duncan's test).

${ }^{*} \mathrm{C} . \mathrm{V}=$ Coefficient of variation.

Two days of $\mathrm{P}$ starvation (-P-P) reduced $\mathrm{NH}_{4}$ uptake by $45.3 \%$ compared with non-P stressed plants (+P-P, Figure 1 and Table 2 ). Resupplying $\mathrm{P}$ activated $\mathrm{NH}_{4}$ absorption (-P+P 150-270 minutes), however, a complete recovery of $\mathrm{NH}_{4}$ uptake was not observed. Ammonium absorption due to early P stress (-P-P) decreased as the length of the $P$ stress increased and achieved a rate of only $16.5 \%$ of the control ( $+\mathrm{P}-\mathrm{P})$ after 10 days of $\mathrm{P}$ starvation (Figure 1). Ammonium uptake, as a function of $\mathrm{P}$ resupply $(-\mathrm{P}+\mathrm{P})$, was $69 \%$ of the control $(+\mathrm{P}+\mathrm{P})$ in plants two days $\mathrm{P}$ stressed and only $28 \%$ of the control in plants stressed for ten days. 
TABLE 2. Ammonium uptake rates by maize after phosphorus stress.

\begin{tabular}{l|c|c|c|c|c}
\hline & \multicolumn{5}{|c|}{ Sampling period (days) } \\
\hline Treatments $\mathrm{a}$ & 2 & 4 & 6 & 8 & 10 \\
\hline$+\mathrm{P}+\mathrm{P}$ & $\begin{array}{c}1.724^{* *} \mathrm{~A} \\
(0-90)^{\mathrm{b}}\end{array}$ & $\begin{array}{c}1.516^{* *} \mathrm{~A} \\
(0-90)\end{array}$ & $\begin{array}{c}1.331^{* *} \mathrm{~A} \\
(0-120)\end{array}$ & $\begin{array}{c}1.325^{* *} \mathrm{~A} \\
(0-210)\end{array}$ & $\begin{array}{c}1.382^{* *} \mathrm{~A} \\
(0-90)\end{array}$ \\
\hline$+\mathrm{P}-\mathrm{P}$ & $1.709^{* *} \mathrm{~A}$ & $1.461^{* *} \mathrm{~A}$ & $1.521^{* *} \mathrm{~A}$ & $1.420^{* *} \mathrm{~A}$ & $1.415^{* *} \mathrm{~A}$ \\
& $(0-120)$ & $(0-90)$ & $(0-90)$ & $(0-150)$ & $(0-90)$ \\
\hline$-\mathrm{P}+\mathrm{P}$ & $0.951^{* * \mathrm{~B}}$ & $0.593^{* * \mathrm{~B}}$ & $0.386^{* * \mathrm{~B}}$ & $\mathrm{ND}$ & $0.289^{* * \mathrm{~B}}$ \\
& $(0-150)$ & $(0-270)$ & $(0-210)$ & & $(0-180)$ \\
\hline$-\mathrm{P}+\mathrm{P}$ & $1.200^{* * \mathrm{C}}$ & $0.661^{* * \mathrm{~B}}$ & $0.626^{* *} \mathrm{C}$ & $\mathrm{ND}$ & $0.385^{* *} \mathrm{C}$ \\
& $(150-270)$ & $(270-360)$ & $(210-310)$ & & $(180-480)$ \\
\hline$-\mathrm{P}-\mathrm{P}$ & $0.935^{* * \mathrm{~B}}$ & $0.565^{* * \mathrm{~B}}$ & $0.377^{* * \mathrm{~B}}$ & $0.381^{* * \mathrm{~B}}$ & $0.234^{* * \mathrm{~B}}$ \\
& $(0-330)$ & $(0-360)$ & $(0-390)$ & $(0-420)$ & $(0-540)$ \\
\hline
\end{tabular}

${ }^{2}$ Treatments: $-\mathrm{P}-\mathrm{P}=$ plants without phosphorus before and during the study period, $-\mathrm{P}+\mathrm{P}=\mathrm{plants}$ without phosphorus before, but supplied phosphorus during the study period, $+\mathrm{P}-\mathrm{P}=$-plants receiving phosphorus prior to, but not during the study period, and $+\mathrm{P}+\mathrm{P}=$ plants supplied phosphorus prior to and during the study period. Data is $\mu \mathrm{mol} \mathrm{NH}_{4}^{+} \mathrm{g}$ root dry weight ${ }^{-1}$ minute ${ }^{-1}$.

**Statistically significant at the $1 \%$ probability level by Student's-t test. Rates followed by the same letter in the columns are not statistically different by Student'st test (pair-wise comparisons).

'Time period (minutes) considered for linear regressions are shown in parenthesis. Values are averages of four replicaitons.

$\mathrm{ND}=$ Not determined.

\section{Comparison of Ammonium with Nitrate Uptake}

Ammonium uptake averaged 3-fold higher than $\mathrm{NO}_{3}$ throughout the 10-day study period (Figure 2). Nitrate uptake of $P$ stressed (-P-P) plants decreased $61 \%$ while $\mathrm{NH}_{4}$ uptake decreased $46 \%$ after two days compared to the P-sufficient control plants ( $+\mathrm{P}+\mathrm{P}$, Figure 2). Although $\mathrm{NH}_{4}$ uptake of $\mathrm{P}$-stressed plants decreased $72 \%$ after six days, $\mathrm{NO}_{3}$ uptake dropped $87.5 \%$. Nitrate uptake stopped 10 days after withholding $\mathrm{P}$ while $\mathrm{NH}_{4}$ uptake was still $17 \%$ of the $\mathrm{P}$-sufficient control.

\section{DISCUSSION}

Ammonium absorption rates are commonly observed to be higher than $\mathrm{NO}_{3}$ (Macklon et al., 1990; Glass and Siddiqi, 1995). When supplied singly, $\mathrm{NH}_{4}$ uptake 


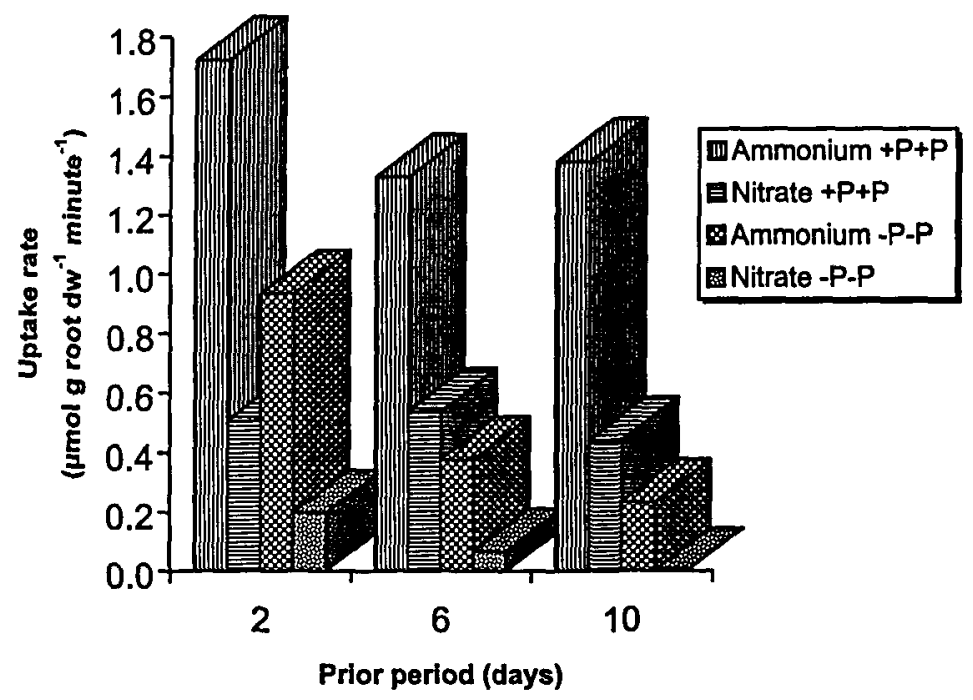

FIGURE 2. Ammonium and nitrate uptake by maize after 2, 6, and 10 days of phosphorus stress. Treatments: -P-P=-plants without phosphorus before and during the study period; $+\mathrm{P}+\mathrm{P}=$ plants supplied phosphorus prior to and during the study period (dw: dry weight).

was much faster than $\mathrm{NO}_{3}$ in Allium cepa $\mathrm{L}$. and this difference became even greater when the two ions were present together in equimolar solutions (Macklon et al., 1990). Although various reasons are given to explain these differences, this research indicates that these preferences may be influenced by the prior nutritional condition of the plants. The genotype used in this experiment (male progenitor of the maize double cross hybrid, BR 201) is a component of a hybrid showing high adaptation to acid soil conditions. Seminal root length in a $6 \mathrm{mg}$ aluminum (Al) $\mathrm{L}^{-1}$ nutrient solution as well as Al induced callose (S.N. Parentoni, personal information), indicate that this male single-cross is the source of $\mathrm{Al}$ tolerance of the hybrid BR 201. Adaptation to strongly acid soils and Al resistance for some tropical grasses involve tolerance to high $\mathrm{NH}_{4}$ concentrations that are toxic to susceptible plants (Blum, 1988). Thus, selection of the BR 201 genotype in acid soils may be a factor related to the observed preference for $\mathrm{NH}_{4}$ since $\mathrm{NH}_{4}$ rather than $\mathrm{NO}_{3}$ may be the predominant form of $\mathrm{N}$ under these conditions.

The higher $\mathrm{NH}_{4}$ than $\mathrm{NO}_{3}$ uptake also may result from a possible inhibition of $\mathrm{NO}_{3}$ influx by $\mathrm{NH}_{4}$. Lee and Drew (1989) reported that $\mathrm{NO}_{3}$ influx in barley was progressively inhibited as the $\mathrm{NH}_{4}$ concentration increased above $0.005 \mathrm{~mol} \mathrm{NH}_{4}$ $\mathrm{m}^{-3}$. The magnitude of $\mathrm{NO}_{3}$ suppression reported by these authors would only partially explain the lower $\mathrm{NO}_{3}$ than $\mathrm{NH}_{4}$ uptake observed in this study (Figure 2). A genotype effect per se would probably account for the kinetic data obtained. 
Although there were differences in $\mathrm{NH}_{4}$ and $\mathrm{NO}_{3}$ uptake between the $\mathrm{P}$ stress treatment and the control (-P-P and $+\mathrm{P}+\mathrm{P}), \mathrm{NH}_{4}$ uptake tended to decrease somewhat less than $\mathrm{NO}_{3}$ and the rates observed for $\mathrm{NH}_{4}$ uptake were still high even when the plants were submitted to $\mathrm{P}$ stress (Table 2, Figure 2). Therefore, $\mathrm{NH}_{4}$ was the main source of $\mathrm{N}$ absorbed by maize plants under $\mathrm{P}$ stress. A significant increase in $\mathrm{NH}_{4}$ uptake of $\mathrm{P}$-stressed plants was observed when they were subsequently supplied $\mathrm{P}(-\mathrm{P}+\mathrm{P})$. Full recovery of $\mathrm{NH}_{4}$ uptake was not observed after resupplying $\mathrm{P}$ even after the shortest period (Table 2, 2 days) of $\mathrm{P}$ stress $(-\mathrm{P}+\mathrm{P}=1.200)$ compared with non-P stressed plants $(+\mathrm{P}+\mathrm{P}=1.724)$. Compared to $\mathrm{NO}_{3}, \mathrm{NH}_{4}$ accounted for most of the total $\mathrm{N}$ absorbed after resupplying $\mathrm{P}$ to $\mathrm{P}$-starved plants. A comparison of the effect of $\mathrm{P}$ resupply on $\mathrm{NH}_{4}(1.200)$ and $\mathrm{NO}_{3}(0.479)$ uptake after two days of $\mathrm{P}$ stress $(-\mathrm{P}+\mathrm{P})$ clearly shows the higher $\mathrm{NH}_{4}$ absorption rate. Similar results were obtained with plants submitted to the other stress periods and then resupplied $\mathbf{P}$.

One hypothetical explanation of these results is the relative energy cost for uptake and assimilation of the two forms of N. Bloom et al. (1992) reported that $14 \%$ of total root carbon catabolism of barley was expended on $\mathrm{N}$ absorption and assimilation under $\mathrm{NH}_{4}$ nutrition and $23 \%$ under $\mathrm{NO}_{3}$ nutrition. The additional energy required for $\mathrm{NO}_{3}$ assimilation could limit growth since energy may be more limited under $\mathrm{NO}_{3}$ than $\mathrm{NH}_{4}$ nutrition. The lower "energy" requirement for $\mathrm{NH}_{4}$ metabolism also is indicated since Q10 values for $\mathrm{NO}_{3}$ uptake are significantly higher than for $\mathrm{NH}_{4}$ uptake (Glass and Siddiqi, 1995). Ammonium nutrition could be most beneficial under conditions of "energy" shortage as probably caused by $P$ stress in maize plants.

Under $\mathrm{NH}_{4} \mathrm{NO}_{3}$ nutrition, the root is the major site of $\mathrm{N}$ assimilation in maize (Murphy and Lewis, 1987). When nutrient elements limit growth, especially $\mathrm{N}$ and $\mathrm{P}$, the roots become stronger carbohydrate sinks than shoots (Clarkson, 1985). The maintenance of root dry matter under P stress conditions in contrast to a decrease in shoots (Table 1), may result from this root carbohydrate sink. Under $\mathrm{NH}_{4}$ nutrition, as a consequence of its complete conversion to organic $\mathrm{N}$ in roots prior to translocation (Ivanko and Ingversen, 1971), an induced carbohydrate sink is established in the root which could create an energy deficiency in other tissues (Magalhaes et al., 1995). In contrast to the rapid assimilation of $\mathrm{NH}_{4}$ in roots, absorbed $\mathrm{NO}_{3}$ is translocated to aerial parts for later reduction and assimilation. This root sink, possibly enhanced by the combination of $\mathrm{P}$ stress and $\mathrm{NH}_{4}$ nutrition, could be an energy disadvantage for $\mathrm{NO}_{3}$, and thereby favor $\mathrm{NH}_{4}$ metabolism. The BR 201 double-cross hybrid maintains high root sugar concentrations (Alves et al., 1995) under $P$ stress conditions and reinforces the root carbohydrate sink theory. The compart-mentalization of $\mathrm{NH}_{4}$ metabolism in roots which are possibly better supplied with energy than shoots, could lead to increased energy utilization efficiency under $\mathrm{NH}_{4}$ nutrition and favor its uptake over $\mathrm{NO}_{3}$.

While $\mathrm{NO}_{3}$ uptake seems to be entirely active at an external concentration range up to $100 \mu \mathrm{mol} \mathrm{L}^{-1}$ (Glass et al., 1992; King et al., 1992), transport of $\mathrm{NH}_{4}$ above an external concentration of $42 \mu \mathrm{mol} \mathrm{L}^{-1}$ could be predicted as a passive process in 
rice (Wang et al., 1994). Although certain conditions, such as the external concentration of $\mathrm{NH}_{4}$ can increase the concentration limit, the occurrence of a partially passive transport can be considered during this study period (Figure 1). Accordingly, Ullrich et al. (1984) reported an inward-directed driving force acted at all external concentrations down to $67 \mu \mathrm{mol} \mathrm{L}^{-1}$. Wang et al. (1994) cautioned that free energy estimations provide only a prediction of the feasibility of the uptake process occurring under the prescribed conditions; however, even with this consideration, a partially passive transport mechanism could contribute to the lower sensitivity for $\mathrm{NH}_{4}$ uptake with $\mathrm{P}$ stress compared to $\mathrm{NO}_{3}$ uptake.

The marked predominance of $\mathrm{NH}_{4}$ in savanna soils after urea application (Coelho, 1995) and the lower sensitivity of $\mathrm{NH}_{4}$ uptake than $\mathrm{NO}_{3}$ uptake to $\mathrm{P}$ stress, suggests that that this single-cross may be physiologically dependent on $\mathrm{NH}_{4}$ rather than $\mathrm{NO}_{3}$ under these conditions. Therefore, this apparent dependence should be considered when practices that affect the $\mathrm{NO}_{3}$ to $\mathrm{NH}_{4}$ ratio in soil, as well as breeding strategies towards the development of genotypes adapted to low $\mathrm{pH}$ conditions, are adopted when aiming for high yield of crops in acid soils.

\section{CONCLUSIONS}

The male progenitor of the $\mathrm{BR} 201$ hybrid showed $\mathrm{NH}_{4}$ uptake rates markedly greater than $\mathrm{NO}_{3}$. These rates remained greater even under $\mathrm{P}$ stress conditions.

Ammonium uptake was decreased by $P$ stress and this reduction was intensified as the length of the stress period increased.

Resupply of $\mathrm{P}$ to plants previously $\mathrm{P}$ stressed activated $\mathrm{NH}_{4}$ uptake. The magnitude of this recovery was dependent on the stress severity. Ammonium uptake was less sensitive to $P$ stress than $\mathrm{NO}_{3}$ uptake.

\section{ACKNOWLEDGMENTS}

This research was supported by the Maize and Sorghum Research Center, EMBRAPA and a scholarship from CNPq-Brazil. The authors thank Wagner Geraldo S. Campos, Gislene Braga Cristeli, and Carla Cristina Moura França for their technical help and friendship.

\section{REFERENCES}

Alves, B.J.R., R.M. Boddey, and S.S. Urquiaga. 1993. A rapid and sensitive flow injection technique for the analysis of ammonium in soil extracts. Commun. Soil Sci. Plant Anal. 24:277-284.

Alves, V.M.C., R.F. Novais, M.F.G. de Oliveira, and P.R. Mosquim. 1995. Açucares solúveis em quatro híbridos de milho sob omissao e sob ressuprimento de fósforo. Revista Brasileira de Fisiologia Vegetal 7(1):97-105. 
Bloom, A. J., S.S. Sukrapanna, and R.L. Warner. 1992. Root respiration associated with ammonium and nitrate absorption and assimilation by barley. Plant Physiol. 99:294-301 .

Blum, A. 1988. Mineral-stress resistance. pp. 133-156. In: Plant Breeding for Stress Environments. CRC Press, Boca Raton, FL.

Clarkson, D.T. 1985. Factors affecting mineral nutrient acquisition by plants. Annu. Rev. Plant Physiol. 36:77-115.

Coelho, A.M. 1995. Efeito de níveis de N-uréia na din,mica de amónia e nitrato em latossolo cultivado e irrigado. pp. 6-11. In: Congresso Nacional de la Ciencia Del Suelo, 7, 1995, Temuco, Chile. Resumen. Universidad de la Frontera, Temuco, Chile..

Foy, C.D., A.L. Fleming, G.P. Burns, and W.H. Arminger. 1967. Characterization of differential aluminum tolerance among varieties of wheat and barley. Soil Sci. Soc. Am. Proc. 31:513-521.

Glass, A.D.M. and M.Y. Siddiqi. 1995. Nitrogen absorption by plant roots. pp. 21-56. In: H.S. Srivastava and R.P. Singh (eds.), Nitrogen Nutrition in Higher Plants. Associated Publishing Co., New Delhi, India.

Glass, A.D.M., J.E. Shaff, and L.V. Kochian. 1992. Studies of the uptake of nitrate in barley. IV. Electrophysiology. Plant Physiol. 99:456-463.

Ivanko, S. and J. Ingversen. 1971. Investigation on the assimilation of nitrogen by maize roots and the transport of some major nitrogen compounds by xylem sap. I. Nitrate and ammonia uptake and assimilation in the major nitrogen fractions of nitrogen-starved maize roots. Physiol. Plant. 24:59-65.

King, B.F., M.Y. Siddiqi, and A.D.M. Glass. 1992. Studies of the uptake of nitrate in barley. V. Estimation of root cytoplasmic nitrate concentration using nitrate reductase activity-Implications for nitrate influx. Plant Physiol. 99:1582-1589.

Lee, R.B. and M.C. Drew. 1989. Rapid, reversible inhibition of nitrate influx in barley by ammonium. J. Exp. Bot. 40(216):741-752.

Macklon, A.E.S., M.M. Ron, and A. Sim. 1990. Cortical cell fluxes of ammonium and nitrate in excised root segments of Allium cepa L.: Studies using ${ }^{15} \mathrm{~N}$. J. Exp. Bot. 41(224):359-370.

Magalhães, J.R., D.M. Huber, and C.Y. Tsai. 1995. Influence of the form of nitrogen on ammonium, amino acids and $\mathrm{N}$-assimilating enzyme activity in maize genotypes. J. Plant Nutr. 18:747-763.

Murphy, A.T. and O.A.M. Lewis. 1987. Effect of nitrogen feeding source on the supply of nitrogen from root to shoot and the site of nitrogen assimilation in maize (Zea mays L. CV. R201). New Phytol. 107:327-333. 
Schjørring, J.K. 1986. Nitrate and ammonium absorption by plants growing at a sufficient or insufficient level of phosphorus in nutrient solutions. pp. 53-58. In: H. Lambers (ed.), Fundamental, Ecological, and Agricultural Aspects of Nitrogen Metabolism in Higher Plants. Martinus Nijhoff, Dordrecht, The Netherlands.

Steel, R.G.D. and J.H. Torrie. 1960. Linear regression. pp. 161-180. In: Principles and Procedures of Statistics. McGraw-Hill Book Company, New York, NY.

Ullrich, W.R., M. Larsson, C.-M. Larsson, S. Lesch, and A. Novacky. 1984. Ammonium uptake in Lemna gibba G 1, related membrane potential changes, and inhibition of anion uptake. Physiol. Plant. 61:369-376.

Vona, V., V. Di Martino Rigano, S. Esposito, C. Di Martino, and C. Rigano. 1992. Growth, photosynthesis, respiration, and intracellular free amino acid profiles in the unicellular alga Cyanidium caldarium. Effect of nutrient limitation and resupply. Physiol. Plant. 85:652-658.

Wang, M.Y., A.D.M. Glass, J.E. Shaff, and L.V. Kochian. 1994. Ammonium uptake by rice roots. III. Electrophysiology. Plant Physiol. 104:899-906.

Wang, M.Y., M.Y.Siddiqi, T.J. Ruth, and A.D.M. Glass. 1993. Ammonium uptake by rice roots. II. Kinetics of ${ }^{13} \mathrm{NH}_{4}{ }^{+}$influx across the plasmalemma. Plant Physiol. 103:1259-1267. 